\title{
同期機の電気的過渡現象解析のための基本式 に関する一考察
}

\author{
正員 田 村 淳 二 (北見工大) \\ 正員 武 田 郁 夫 (北見工大)
}

\section{A Consideration on Basic Equations for Electrical Transients of Synchronous Machines}

Junji Tamura, Member, Ikuo Takeda, Member (Kitami Institute of Technology)

Not a few types of $d$-and $q$-axis equivalent circuits for analysis of electrical transients of synchronous machines have been proposed. However these circuits, in general, have the same structure fundamentally except the rotor circuit composed of field and damper circuits. Therefore these several types of $d$ - and $q$ - axis circuits may be considered to have some properties in common. This paper investigates the fundamental properties of $d$ - and $q$-axis equivalent circuits and basic equations by using the generalized $d$-and $q$-axis circuits whose rotor circuits are expressed by two-port networks.

At first, the generalized $d$-and $q$-axis equivalent circuits are shown and the basic equations for analysis of electrical transients are derived from them. And the basic properties of the four transfer functions ( $d$ - and $q$-axis operational inductances, and two armature-to-field transfer functions) appearing in the basic equations are analyzed. Next, some problems encountered on constructing $d$ - and $q$-axis circuits by using these transfer functions are noted. Finally, the fundamental theory of three test methods which are based on the determination of the transfer functions (frequency response method, three-phase short circuit test and stator decrement test) are developed by using the basic equations derived here, and their fundamental meanings are clarified.

キーワード : 同期機, $d, q$ 軸等偳回路, オペレーショナルインダクタンス, 定数決定法

\section{1.まえがき}

本論文は，同期機の電気的過渡現象解析のための基 本式に関して検討を行い，その一般的な特性を明らか にするものである。ただし，機械的過渡現象は考察の 対象外とするので, 回転子の回転速度は時間的に不変 であることを前提とする。同期機の $d, q$ 軸等価回路 および基本回路方程式を構成する際, 制動回路の表現 が問題となる。突極形の水車発電機に対しては図 1 に 示す伝統的な等価回路が標準的に用いられる反面，塊 状鉄心構造のタービン発電機においては制動回路の表 現は特に複雑である。後者に関しては次章で述べる上
うに近年非常に多くの検討がなされ，種々の回路が提 案されている。その結果として，定数決定手法に関し てまだ多少問題が残されているものの，実用的に十分 な精度を与えるような幾つかの等価回路（例元ば図 2）が推奨されている。ところで，これらの等価回路 は基本的にその制動回路の構造が異なるだけであり， 本質的には類似の性質を有し，それぞれの回路に対す る基本式は種々の共通的な性質を有するものと考えら れる。本資料はこの点に着目し，多種多様の構成とな り得る制動回路を含めて回転子回路全体を二端子対回 路を用いたブラックボックスで表現して基本式を導出 し，その一般的な性質を明らかにしようとするものて 


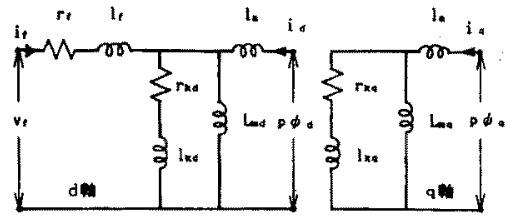

図 $1 d, q$ 翰等価回路 (I)

Fig. 1. $d$ - and $q$-axis equivalent circuits (I).
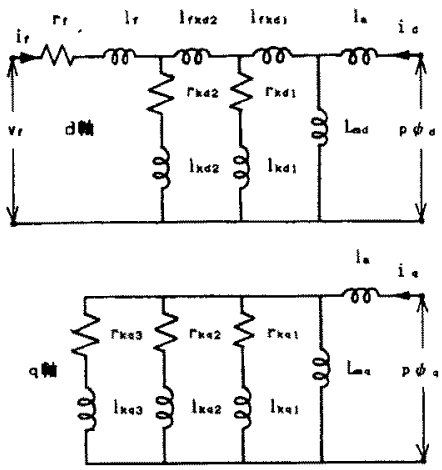

図 $2 d, q$ 軸等価回路 (II)

Fig. 2. $d-$ and $q$-axis equivalent circuits (II).

ある。同期機の基本式をこのように一般的な形式で論 じた報告は非常に少なく，また本資料ては基本式㧈よ びそこに現れる伝達関数の性質に関して検諳すると共 に，後半てはこれらの伍達関数に基礎を固く代表的な 定数決定法と基本式との関連に関しても検討を加えて おり，同期機の基礎理論の総合的把握のための有用な 資料を与えると考えられる。

\section{2. 同期機の $d, q$ 軸等価回路構成の变遷}

同期機ゆ電気的過渡現象解析のための一般的な基本 回路方程式を初めて示したのはParkである ${ }^{(6)}$ 。その 後, この基本式を出発点として同期機の等価回路や数 学的モデルに関する研究が続けられることになるが、 その際問題となるのが回転子側 (界磁側) 回路の表現 である。これについては，結局界磁回路のはかにd， q軸にそれぞれ1個の制動回路を考慮する方法が広く 認められ，現在に至るまで同期機の標整的なモデルと して用いられている(1)心(5)。これが図1に示す標準モ

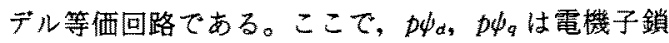
交磁束の時間微分, $v_{f}$ は界磁電圧， $l_{a}, L_{m d}, L_{m q}$ は 電機子漏れインダクタンスおよび主磁束励磁インダク タンスであり，他の抵抗および漏れインダクタンスに

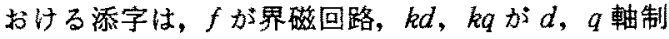
動回略を表す（図 2 についても同様）。しかしながら， 1960 年代ごろから図 1 の等価回路の不十分さが指摘 されるようになり，等価回路の改良ならびにそれに対 応する定数決定法が研究されるようになった。Canay は界磁電流の応答を正確に求めるためには，いわゆる Mutual Leakage インダクタンス（以後“相互漏れイ ンダクタンズと呼ふ，図 2 でいえば $l_{f k d 1}, l_{f k d 2}$ であ る）の考慮が不可久であることを指摘し(7)，タービン 発電機と突極機に対する等価回路を設計論的見地から 導出した ${ }^{(9)(10)}$ 。後に，図 1 の標準モデルにこの相互漏 クインダクタンスを考慮した場合の三相突発短絡試験 による定数決定法も示された

一方，アメリカにおいても Jacksonらがタービン 発電機に站する正確な等価回路 ${ }^{(8)}$ 示したのに引統 き, Schulzらはこの回路に周波数応答法の考え方を導 入することによりタービン発電機に対する最初の実用 的かつ詳紏な等洒回路を導出した(これは図 2 と $q$ 軸は 同じであるが，d軸がわずかに筫なる) (1)。その後， 周波数広答の奏測值を基に等価回路を構成する手法が 検討されるようになり，静止周波数応答試験 ${ }^{(12)(17)(22), ~}$ オンライン周波数応答試験 ${ }^{(19)(23)(24)}$ などによる各伝達 関数の澌定ちよび等価回路の構成が検討され，一方， 周波数応答特性を有限要素法に基つくく磁界計算によっ

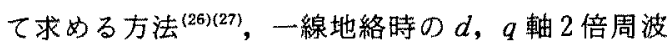

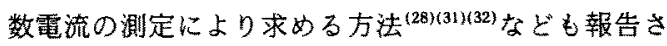
れている。

以上のような経過をふまえて, 文献(30)ではタービ ン発電機に対する実用的かつ最も精度の高いモデルと して図2の詳細モデルを，また取扱いが容易で必要㵊 小限の精度を有するものとして図 2 の回路より $d, q$ 軸とも制動回路を 1 個ずつ取除いたモデルを推奨して いる(p.78)。また，水車発電機に対しては，図 1 に相 互漏れインダクタンスを考慮したモデルを推桨してい る。なお我が国においては，氷車発電機に対しては図 1のモデルが、タービン発電機に対しては図 1 におい てq軸制動回路を2個としたモデルが主として用い られている(36)(37)。

\section{3. 同期機の電気的過渡現象解析のための 基本式}

本章では，同期機の電気的過渡現象解析のための基 本式を一般的な形式で導出する。つまり，物理的な見 地加らみて明らかと考えられる部分を明りょうな電気 回路で構成し，確定的でない部分をブラックポックス で表現し，その入出力特性に着目する。 $d, q$ 軸等価

電学論D, 111 巻 5 号, 平成 3 年 
回路においては，一般にその電機子回路部分の構成は 明確であり,一方, 前述したように回転子側回路の構 造は主として制動回路の複雑さによって明確であると は言いがたい。そこで以下では，回転子回路の部分を ブラックボックス,つまり二端子対回路で表現して基 本式を導出する。

な㧍，界磁回路の構成は巻線抵抗と漏れインダクタ ンスの直列接続回路で表すことができると考えられる が*，ここではこれもブラックボックスに含めて扱う ことにする。ただし $F$ パラメータを用いるので，二 端子対回路部分が幾つかの回路の縦続接続として表現 される場合への拡張は容易である。

\section{〈3・1〉基本式の導出前述のように界磁回路,} 制動回路の部分を $F$ パラメータで表現して回路方程 式を導出する。この際, 以下の仮定を設ける。

(1) 回転子側（界磁側）回路は既に $d, q$ 軸電機 子巻線側に等価変換されているとする。従って， $d$, $q$ 軸ともそれぞれ共通の主磁束励磁インダクタンスを 有する等価回路で表現される(文献 (4) p. 147)。電機 子および界磁の端子状態量の測定によって回路同定を 行引際, 界磁の電圧・電流に対して適当な基準值を用 いれば, 結果として得られる回路は電機子儧基準值に 対する回路,つまり電機子側に等価換算された等洒回 路となる ${ }^{(35)}$ 。

（2）主磁束通路を除く磁気回路に扔ける鉄心の七 ステリシスや磁気飽和などに基づく非線形性は無視す る。従って,これらの部分は抵抗およびインダクタン スから成る線形の回路で表現できるものとする。な お，主磁束の飽和は励磁インダクタンスの変化という 形で通常扱うことができる。

以下では，文献(4)にならってラプラス変換を基嘫 として解析を進めるが,ささしたたり電圧, 電流などに おける定常值からの変化分を状態変数として扱う。ま た, 制動回路の電流の初期值は初めから０として扱 う。まず $d, q$ 軸の等価回路を図 $3 て ゙$ 表す。 $\Delta$ を付し たものは変化分を表し， $s$ はラプラス演算子である。 $V_{d}(s), V_{f}(s), E_{v d}(s), I_{d}(s)$ などは電機子電圧, 界 磁電圧, 速度起電力, 電機子電流の裏領域変数であ $\eta, L_{m d}, L_{m q}, l_{a}, r_{a}$ は $d, q$ 軸主磁束励磁インダ クタンス, 電機子漏れインダクタンス, 電機子抵抗で ある。回転子回路部分の $F$ パラメータを図のように $A_{d}, B_{d}, C_{d}, D_{d}$ とすると,以下の式が成り立つ。

* たたしCanayは，界磁か腒磁電源により短絡されている場合

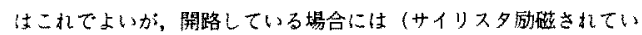
一励磁䉓流が道極性になる場合を含む)界磁抵抗と並列に渦電流回 路考考虑すべきであると述へている(文献(16) p. 144)。

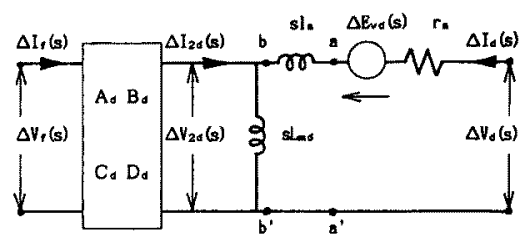

(a)

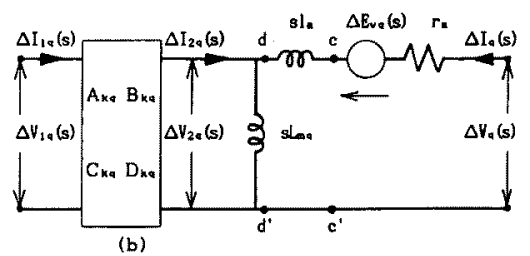

図 3 一般的な $d, q$ 軸等価回路

Fig. 3. Generalized $d$ - and $q$-axis equivalent circuits.

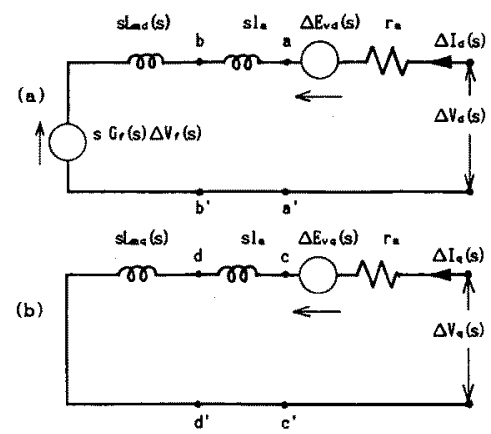

図 4 簡略化 $d, q$ 軸等価回路

Fig. 4. Simplified $d$-and $q$-axis equivalent circuits.

$$
\left.\begin{array}{l}
\Delta V_{f}(s)=A_{d} \Delta V_{2 d}(s)+B_{d} \Delta I_{2 d}(s) \\
\Delta I_{f}(s)=C_{d} \Delta V_{2 d}(s)+D_{d} \Delta I_{2 d}(s)
\end{array}\right\}
$$

（1）式を基に，(a)図の $b-b^{\prime} よ り$ 左側をテブナンの 等価回路で表現すると，その結果が図 4(a) となる。 $q$ 軸に関しても $F$ パラメータを $A_{k q}, B_{k q}, C_{k q}$, $D_{k q}$ として, $\Delta I_{1 q}(s)=0$ の条件の下で同様な等価回路 を求めると,その結果が(b)図となる。ただし,

$$
\left.\begin{array}{l}
s G_{f}(s)=s L_{m d} /\left(s L_{m d} A_{d}+B_{d}\right) \\
s L_{m d}(s)=s L_{m d} B_{d} /\left(s L_{m d} A_{d}+B_{d}\right) \\
s L_{m q}(s)=s L_{m q} D_{k q} /\left(s L_{m q} C_{k q}+D_{k q}\right)
\end{array}\right\}
$$

である。次に，図3，図4のそれぞれa-a，c-c'間 の電压が等しいとおいて 


$$
\left.\begin{array}{l}
s L_{m d}\left\{\Delta I_{2 d}(s)+\Delta I_{d}(s)\right\}+s l_{a} \Delta I_{d}(s) \\
=s L_{d}(s) \Delta I_{d}(s)+s G_{f}(s) \Delta V_{f}(s) \\
s L_{m q}\left\{\Delta I_{2 q}(s)+\Delta I_{q}(s)\right\}+s l_{a} \Delta I_{q}(s) \\
=s L_{q}(s) \Delta I_{q}(s)
\end{array}\right\}
$$

が得られる。ただし，

$$
\left.\begin{array}{l}
L_{d}(s)=l_{a}+L_{m d}(s) \\
L_{q}(s)=l_{a}+L_{m q}(s)
\end{array}\right\}
$$

一方, $d, q$ 軸の電機子鎖交磁束を $\Psi_{d}(s), \Psi_{q}(s)$ と すると

$$
\left.\begin{array}{l}
\Delta \Psi_{d}(s)=L_{m d}\left\{\Delta I_{2 d}(s)+\Delta I_{d}(s)\right\}+l_{a} \Delta I_{d}(s) \\
\Delta \Psi_{q}(s)=L_{m q}\left\{\Delta I_{2 q}(s)+\Delta I_{q}(s)\right\}+l_{a} \Delta I_{q}(s)
\end{array}\right\}
$$

となるので, 各速度起電力は回転子角速度を $\omega_{m}$ と抒 いて次式で表されることになる。

$$
\left.\begin{array}{rl}
\Delta E_{v d}(s) & =\omega_{m} \Delta \Psi_{q}(s)=\omega_{m} L_{q}(s) \Delta I_{q}(s) \\
\Delta E_{v q}(s) & =-\omega_{m} \Delta \Psi_{d}(s) \\
& =-\omega_{m}\left\{L_{d}(s) \Delta I_{d}(s)+G_{f}(s) \Delta V_{f}(s)\right\}
\end{array}\right\}
$$

以上の諸式および図 4 より，変化分に関する基碟回路 方程式が次式として得られる。

$$
\left.\begin{array}{rl}
\Delta V_{d}(s)= & \left\{r_{a}+s L_{d}(s)\right\} \Delta I_{d}(s) \\
& -\omega_{m} L_{q}(s) \Delta I_{q}(s)+s G_{f}(s) \Delta V_{f}(s) \\
\Delta V_{q}(s)= & \left\{r_{a}+s L_{q}(s)\right\} \Delta I_{q}(s) \\
& +\omega_{m} L_{d}(s) \Delta I_{d}(s)+\omega_{m} G_{f}(s) \Delta V_{f}(s)
\end{array}\right\}
$$

次に，(1)式抽よび図 3(a)より得られる

$$
\Delta V_{2 d}(s)=s L_{m d}\left\{\Delta I_{2 d}(s)+\Delta I_{d}(s)\right\} \quad \cdots \cdots(8)
$$

より $\Delta I_{d}(s)$ と $\Delta I_{f}(s)$ の関係式を計算すると，その結 果が次式となる。

$$
\begin{aligned}
& \Delta I_{f}(s)=G_{f}^{\prime}(s) \Delta V_{f}(s)-s G_{d}(s) \Delta I_{d}(s) \\
& G_{f}^{\prime}(s)=\left(s L_{m d} C_{d}+D_{d}\right) /\left(s L_{m d} A_{d}+B_{d}\right) \\
& A_{d} D_{d}-B_{d} C_{d}=1
\end{aligned}
$$

ただし，(9)式の下線部が(2)式の定義による $G_{f}(s)$ となるためには(11)式が成り立つことが条件となる。 考察の対象としている二端子対回路は線形受動素子か ら成る可逆回路であるので，(11)式は当然成立する。 以上に扔いて，各変化分を初期值を用いて

$$
\left.\begin{array}{l}
\Delta V_{d}(s)=V_{d}(s)-v_{d 0} / s \\
\Delta I_{d}(s)=I_{d}(s)-i_{d 0} / s
\end{array}\right\}
$$

などとして表して，これを(7)，（9)式に代入して最
終的に次式を得る。

$$
\left.\begin{array}{rl}
\left\{V_{d}(s)-v_{d 0} / s\right\}= & \left\{r_{a}+s L_{d}(s)\right\}\left\{I_{d}(s)-i_{d 0} / s\right\} \\
& -\omega_{m} L_{q}(s)\left\{I_{q}(s)-i_{q 0} / s\right\} \\
& +s G_{f}(s)\left\{V_{f}(s)-v_{f 0} / s\right\} \\
\left\{V_{q}(s)-v_{q 0} / s\right\}= & \left\{r_{a}+s L_{q}(s)\right\}\left\{I_{q}(s)-i_{q 0} / s\right\} \\
& +\omega_{m} L_{d}(s)\left\{I_{d}(s)-i_{d 0} / s\right\} \\
& +\omega_{m} G_{f}(s)\left\{V_{f}(s)-v_{f 0} / s\right\} \\
\left\{I_{f}(s)-i_{f 0} / s\right\}= & G_{f}^{\prime}(s)\left\{V_{f}(s)-v_{f 0} / s\right\} \\
& -s G_{f}(s)\left\{I_{d}(s)-i_{d 0} / s\right\}
\end{array}\right\}
$$

上式が電気的過渡現象解析のための基本式であり, 制 動回路の電流初期值（=0）が含まれていない点を除 いて従来の式〔文献 (4) p. 175] と同じ形であるが, 制 動回路の構造に関して一般性をもたせた点でより一般 的である。（3），(5)式によって磁束鎖交数を変数と して組入れると

$$
\begin{aligned}
& \Delta \Psi_{d}(s)=\Psi_{d}(s)-\psi_{d 0} / s \\
& =L_{d}(s)\left\{I_{d}(s)-i_{d 0} / s\right\} \\
& +G_{f}(s)\left\{V_{f}(s)-v_{f 0} / s\right\} \\
& \Delta \Psi_{q}(s)=\Psi_{q}(s)-\phi_{q 0} / s \\
& =L_{q}(s)\left\{I_{q}(s)-i_{q 0} / s\right\} \\
& \left\{V_{d}(s)-v_{d 0} / s\right\}=r_{a}\left\{I_{d}(s)-i_{d 0} / s\right\} \\
& +s\left\{\Psi_{d}(s)-\phi_{a 0} / s\right\} \\
& -\omega_{m}\left\{\Psi_{d}(s)-\psi_{q 0} / s\right\} \\
& \left\{V_{q}(s)-v_{q 0} / s\right\}=r_{a}\left\{I_{q}(s)-i_{q 0} / s\right\} \\
& +s\left\{\Psi_{q}(s)-\phi_{q 0} / s\right\} \\
& +\omega_{m}\left\{\psi_{d}(s)-\psi_{d 0} / s\right\}
\end{aligned}
$$

が得られ、これはParkが示した基本式にほかなら ない。

〈3.2〉伝達関数の意義に関する考察（13）式よ り $\omega_{m}$ 一定時における電気的過渡現象は基本的に 4 個 の伝達関数により決まることが明らかである。つまり オペレーショナルインダクタンス $L_{d}(s), L_{q}(s)$ およ び $G_{f}(s), G_{f}^{\prime}(s)$ である。同期機の種々の過渡現象解 析を行うためには, これらの伝達関数を決定すること が必要となる。さて, それぞれの伝達関数の意義に関 して以下のことを結論づけることができる。

（1）界磁電圧一定時において, 電機子電流の応答 を正確に求めるためには $L_{d}(s), L_{q}(s)$ が必要である。

（2）上記の場合に界磁電流の応答も正確に求める ためには $G_{f}(s)$ も必要となる。

（3）界磁電圧も変化する場合, 電機子電流の応答 を求めるためには $L_{d}(s), L_{q}(s), G_{f}(s)$ が必要で ある。 
（4）上記（３）項の場合に界磁電流の応答も求める ためには更に $G_{f}^{\prime}(s)$ も必要となる。

言うまでもなく，任意の状況下においてすべての過 渡現象を正確に求めるためには 4 個の関数すべてが必 要であり，これは言い換えれば，図 3 の二端子対回路 は四端子定数のすべての情報に基づいて構成する必要 があるということである。従来の等洒回路の同定で は, 多くの場合 $L_{d}(s), L_{q}(s), G_{f}(s)$ の 3 個のみが扱 われているが,これは (2)式より $d$ 軸に関して $A_{d}$, $B_{d}$ に関する情報のみによって回転子回路を構成して いることに相当し，回転子回路の構造が物理的に明白 であって $A_{d} ， B_{d}$ と $C_{d}, D_{d}$ とが従属関係になるよ うな回路構成となる場合を除いて, 前記 (4)項の要求 に対して满足すべき結果を与える保証はないことにな る。ただし，(13)，(14)式より明らかなように，これ ら3 個の伝達関数を考慮することにより, 任意の状況 下において電機子の電流と鎖交磁束の応答は正確に求 まるので, 従って発生トルクも正確に計算できること になり，負荷角の応答を対象とする安定度解析のため にはこれで十分であるともいえる。一方， $q$ 軸に関し ては, 必要なのは電機子側の状態量の計算であり, $L_{q}(s)$ のが決定されればよい。これは(2)式より四 端子定数のうちの $D_{k q} / C_{k q}$ (右側より二端子対回路を 眺めたときの駆動点インピーダンス)に関する情報の みによって回転子回路を構成することに相当し, 物理 的な見地からは不正確であるが，電機子電流の計算の ためにはこれで十分である。q軸では回転子側の状態 量を検出できないので，測定によって四端子定数を独 立に,つまり回路の棈造を完全に決定することは不可 能である。

〈3.3〉伝達関数の構造に関する考察 二つの極 限状態 $(s=0, s=\infty)$ における四つの伝達関数の構造 に関して前出の諸式，図 30 等価回路を基に検討す る。まず初めに $s=0$ の場合を想定すると, 等価回路 上の電圧，電流はすべて直流となる（つまり，これは 定常運転状態を意味する)。たたし，回転数は同期速 度一定, 電機子電圧には逆相分が含まれず, 界磁電圧 は正確な直流であることを前提とする。このときには 電機子電流 $i_{d}$ はそのすべてが $L_{m d}$ に流入し, かつ $L_{\pi d}$ の両端の電位差は 0 となる。従って $i_{d}$ による電 機子鎖交磁束成分は $\left(l_{a}+L_{m d}\right) i_{d}$ となり，結局オペレ ーショナルインダクタンスの值が一定值 $l_{a}+L_{m d} に$ なることを意味する。一方，界磁電流もそのすべてが $L_{m a}$ に流入し, 界磁電圧を $v_{f}$, 界磁巻線抵抗を $r_{f}$ と すればこれは $v_{f} / r_{f} に$ 等しくなり，よって界磁電圧に よる電機子鎖交磁束成分は $L_{m d} v_{f} / r_{f}$ となる。なお，
もし二端子対回路内に $L_{m d}$ と並列にインダクタンス のみから成るループを構成するような枝路があるとす れば上述のことは成り立たないが，これはありえない ことである。なぜならば，もしこのような枝路があれ ば定常状態において電流が流れるような制動回路が存 在することになるからである。以上のことは $q$ 軸に 関しても同様であり，よって次式が得られる。

$$
\left.\begin{array}{l}
L_{d}(s=0)=l_{a}+L_{m d}=L_{d} \\
L_{q}(s=0)=l_{a}+L_{m q}=L_{q} \\
G_{f}(s=0)=L_{m d} / r_{f}
\end{array}\right\}
$$

一方， $G_{f}^{\prime}(s)$ は (13) 式より電機子回路を開路したとき の界磁側より眺めた等価インピーダンスの逆数に相当 するので, 前記の考察より次式が成り立つ。

$$
G_{f}^{\prime}(s=0)=1 / r_{f}
$$

次に, $s$ が無限大となった場合の特性に関して, 各 四端子定数の意味を基にして検討する。 $A_{d}, B_{d}$, $C_{d}, D_{d}$ はs 領域におけるブラックボックス内の諸イ ンピーダンスの関数であるが， $A_{d}, D_{d}$ は電圧比，電 流比を与える係数であるから無次元の量であり， $B_{d}$, $C_{d}$ は $s$ 領域におけるインピーダンス, アドミタンス の次元を有する㽞である。よって，これらを一般的に 次のように表現することができる。

$$
\left.\begin{array}{rl}
A_{d} & =\frac{\alpha_{0}+\alpha_{1} s+\cdots+\alpha_{i} s^{i}}{\beta_{0}+\beta_{1} s+\cdots+\beta_{i} s^{i}} \\
B_{d} & =\frac{\gamma_{0}+\gamma_{1} s+\cdots+\gamma_{j+1} s^{j+1}}{\varepsilon_{0}+\varepsilon_{1} s+\cdots+\varepsilon_{j} s^{j}} \\
C_{d} & =\frac{\zeta_{0}+\zeta_{1} s+\cdots+\zeta_{m} s^{m}}{\eta_{0}+\eta_{1} s+\cdots+\eta_{m+1} s^{m+1}} \\
D_{d} & =\frac{\mu_{0}+\mu_{1} s+\cdots+\mu_{n} s^{n}}{\nu_{0}+\nu_{1} s+\cdots+\nu_{n} s^{n}}
\end{array}\right\}
$$

各式の分母, 分子における $\alpha_{0}, \beta_{0}, i, j$ な゙は単な る定数であるが，これらのうち少なくともsの最大次 数項の係数 $\alpha_{i}, \beta_{i}$ などが 0 となることはない。よっ て，上式と（2）式より，例之ば $L_{d}(s)$ に関して次式が 得られる。

$$
\begin{aligned}
\operatorname{Lim}_{s \rightarrow \infty}\left(L_{d}(s)\right] & =l_{a}+\frac{L_{m d}\left(\gamma_{j+1} / \varepsilon_{j}\right)}{L_{m d}\left(\alpha_{i} / \beta_{i}\right)+\left(\gamma_{j+1} / \varepsilon_{j}\right)} \\
& =0 \text { でない有限值 } \cdots \cdots \cdots \cdots \cdots \cdots \cdots \cdots \cdots \cdots \cdots
\end{aligned}
$$

全く同様にして以下の関係式が得られる。

$$
\left.\begin{array}{l}
\operatorname{Lim}_{s \rightarrow \infty}\left[L_{q}(s)\right]=0 \text { でない有限值 } \\
\operatorname{Lim}_{s \rightarrow \infty}\left[s G_{f}(s)\right]=0 \text { でない有限值 } \\
\operatorname{Lim}_{s \rightarrow \infty}\left[s G_{f}^{\prime}(s)\right]=0 \text { でない有限值 }
\end{array}\right\}
$$

以上により 4 個の伝達関数の境界条件が明らかとな ったが，この条件は次章でこれらを有理関数で表現す 
る際に有用な情報を与えることになる。

\section{4. 伝達関数の関数表現と等価回路の構成}

$\langle 4: 1\rangle$ 伝達関数の有理関数表現 前出の伝達関 数に基づく端子状態量の剆定結果から同期機の等価回 路を構成する場合，まず測定値を基に(13)式に現れた 4 個の伝達関数を最終的な回路構成を念頭におきつつ 任意の関数で表現し，次にこれら関数表現された伝達 関数と同じ端子特性を有するような等価回路を决定す

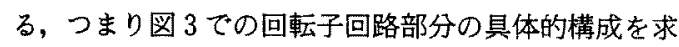
めるというのが基本的過程である。従ってこの場合に はまず初めにこれらの伝達関数をどのような関数形 に設定するかというのが重要な問題となる。この関数 形の决定に際しては, ある程度の自由度はあるもの の, 前章で導出した境界条件を満たすことが必要とな る。本章では，最も基本的であり，かつ現実に最も多 く採用されているものとして，伝達関数を有理関数で 表現した場合における取扱いについて考察をはらう。 この場合には，対応して得られる回転子回路が図 1, 図2のように一定の抵抗とインダクタンスのみから成 る単純な回路となり，その取扱いは容易である。

4 個の伝達関数 $L_{d}(s), L_{q}(s), G_{f}(s), G_{f}^{\prime}(s)$ を単 純な有理関数で表すこととし，更に前章で得られた境 界条件(16) （20)式も考慮すると，一般的にこれらを 次のように置くことができる。ただし，(2)，(10)式 より $d$ 軸の 3 個の関数の分母はすべて同じとしなけ ればならない。

$$
\left.\begin{array}{l}
L_{d}(s)=L_{d} \frac{1+a_{1} s+a_{2} s^{2}+\cdots+a_{N} s^{N}}{1+d_{1} s+d_{2} s^{2}+\cdots+d_{N} s^{N}} \\
G_{f}(s)=\frac{L_{m d}}{r_{f}} \frac{1+b_{1} s+b_{2} s^{2}+\cdots+b_{N-1} s^{N-1}}{1+d_{1} s+d_{2} s^{2}+\cdots+d_{N} s^{N}} \\
G_{f}^{\prime}(s)=\frac{1}{r_{f}} \frac{1+c_{1} s+c_{2} s^{2}+\cdots+c_{N-1} s^{N-1}}{1+d_{1} s+d_{2} s^{2}+\cdots+d_{N} s^{N}} \\
L_{q}(s)=L_{q} \frac{1+e_{1} s+e_{2} s^{2}+\cdots+e_{N} s^{M}}{1+f_{1} s+f_{2} s^{2}+\cdots+f_{N} s^{M}}
\end{array}\right\}
$$

上式は更に次のように変形することができる。

$$
\begin{aligned}
L_{d}(s) & =L_{d} \frac{\left(1+s T_{d 1}\right) \cdots\left(1+s T_{d N}\right)}{\left(1+s T_{d 01}\right) \cdots\left(1+s T_{d 0 N}\right)} \\
G_{f}(s) & =\frac{L_{m d}}{r_{f}} \frac{\left(1+s T_{d A 1}\right) \cdots\left(1+s T_{d A(N-1)}\right)}{\left(1+s T_{d 01}\right) \cdots\left(1+s T_{d O N}\right)} \\
G_{f}^{\prime}(s) & =\frac{1}{r_{f}} \frac{\left(1+s T_{d B 1}\right) \cdots\left(1+s T_{d B(N-1)}\right)}{\left(1+s T_{d 01}\right) \cdots\left(1+s T_{d 0 N}\right)} \\
L_{q}(s) & =L_{q} \frac{\left(1+s T_{q 1}\right) \cdots\left(1+s T_{q M}\right)}{\left(1+s T_{q 01}\right) \cdots\left(1+s T_{q 0 M}\right)}
\end{aligned}
$$

従って, 試験結果を基にして各係数と時定数の值を決
定すればよいことになる。ただし，NとMの値は回 路の物理的構造も考盧しつつ試験結果をどの程度の精 度で近似するかという観点から決定される。一般に， 図 3 において励磁インダクタンスと回転子回路を合せ た部分における独立な電流ループの数か゚ $N, M$ とな る。

〈4・2〉回転子回路粠成における注意点試験結 果を基に(22)式の形の関数を求めて，具体的に図 3 の 回転子回路部分を構成する際，注意しなければならな い問題点がある。手順としては，まず制動回路の物理 的構成や全体としての精度を考慮して $N, M$ を決定 し，それに対する回転子回路の具体的構成を決定す る。次に, 試験結果を $N, M$ の值に対応する関数で 近似し，(22)式における係数，時定数の値を求める。 一方, 構成された回路より伝達関数を(22)式の形で表 し, 各係数, 時定数の式を求め, これらを先の係数 値, 時定数値に等しいとおいて方程式を構成し,これ を解くことによって等価回路定数が求まる。この際, 回路同定に用いる伝達関数と回路の構成に応じて, 末 知数である等価回路定数の数と, 方程式の数は必ずし も一致しないことに注意する必要がある。後述するよ うに，laはあらかじめその值が決定されているとし て，例えば図 1 のd軸回路を $L_{d}(s)$ のみに関する試 験結果より決定する場合 $(N=2)$ に, 試験值 $L_{d}$, $T_{d 1}, T_{d 2}, T_{d 01}, T_{d 02}$ に対して未知数は, $L_{m d}, r_{k d}, l_{k d}$, $r_{f}, l_{f}$ となり一意に解けるが, 一方, 図 $20 d$ 軸回 路を $L_{d}(s), G_{f}(s)$ の試験結果より決定する場合 $(N$ -3), 方程式の数は 10 本となるが末知数の数が 9 個 となり，いずれか 1 本の式を使用しないで解くなどの 近似的処理が必要となる(33)。ただし, 非線形方程式 となるので，その报いは比較的複雑である(文献 (19) Part-1, Appendix A]。なお， $q$ 朝回路の同定におい ては, $L_{q}(s)$ に関する試験值のみしか得られないので あるが，図2のような抵抗とインダクタンスの直列回 路による単純並列接続として制動回路を構成する場合 には, 試験值と末知数の数が一致し，箪純な代数的処 理で解が得られる ${ }^{(12)}$ 。

以上のような計算において，方程式の中に電機子漏 れインダクタンスlが入ってくるが，一般にこれを 末知数として扱うことはできず，あらかじめその值を 設定する必要がある。ところが, 電機子漏れインダク タンスの值を測定によって正確に求めることは一般に 困難であり，通常は設計理論に基づく計算值が使用さ れる。なお，la の值は必ずしも電機子漏れインダク タンスに等しくする必要はなく，任意の值でよいこと が知られている(文献(17) p. 272)。この性質を利用し 
て，例えば $l_{a}=0$ である回路や，また相互漏れインダ クタンスを消去した回路も提案されている(25)(34)。し かし, 以上の上うな回路仗実際の回路の物理的構造と の対応がとれていないことはもちろんのこと, 主磁束 の飽和によって励磁インダクタンスが変化する場合に 飽和の程度に応じて回転子回路のすべての定数值を変 えなければならない(文献(34) p. 597，Dandenoの討 論参照了などの欠点があり，あまり実用されない。

\section{5. 各種試験法と伝達関数の関係}

本章では，同期機の定数決定法のうち伝達関数の決 定に基礎を㧈くものから代表的な三つを取上け゚，試験 結果と先の伝達関数との関係に視点を置きつつそれぞ れの基本原理を説明する。

$\langle 5 \cdot 1\rangle$ 周波数応答試験 ${ }^{(17)(20)(38)}$ 静止周波数応答 試験では，電機子を単相結線とし，その磁軸が界磁磁 軸と一致 ( $d$ 軸測定), あるいは直交 ( $q$ 軸測定)す るように回転子を固定し, 界磁回路は場合に応じて短 絡または開路状態とし, 電機子側より $f=1 \mathrm{mHz}$ 数 百 $\mathrm{Hz}$ 程度の周波数範井の交流電圧を供給して電機子 電流，界磁電流などを測定する。例えば，界磁短絡の 場合に扔ける $d$ 軸関係式は (13)式より次式となる。

$$
\left.\begin{array}{l}
\left\{V_{d}(s)-v_{d 0}(s)\right\}=\left\{r_{a}+s L_{d}(s)\right\}\left\{I_{d}(s)-i_{d 0} / s\right\} \\
\left\{I_{f}(s)-i_{f 0} / s\right\}=-s G_{f}(s)\left\{I_{d}(s)-i_{d 0} / s\right\}
\end{array}\right\}
$$

この場合は交流回路理論に基づき $s$ を $2 \pi f$ とし, 各 変数をフェーザとおき，初期值をすべて 0 として扱う ことができるので,

$$
\left.\begin{array}{l}
L_{d}(j 2 \pi f)=\left\{\dot{V}_{d} / \dot{I}_{d}-r_{a}\right\} / j 2 \pi f \\
G_{f}(j 2 \pi f)=-\left(\dot{I}_{f} / \dot{I}_{d}\right) / j 2 \pi f
\end{array}\right\}
$$

となり， $v_{\boldsymbol{d}} ， i_{d} ， i_{f}$ の測定により $L_{d}(s), G_{f}(s)$ の周 波数特性が求められ，これを近似するような適当な $N$ における(22)式の関数に扔ける係数, 時定数の值 を最小二乗法などで求めれば（一般に大きさと位相の 両方を考慮する), 前章で述べたような過程で等価回 路構成が行元る。q 軸についても同様である。なお， 界磁を開放した場合における式は次式となり，

$$
\left.\begin{array}{l}
\left\{V_{d}(s)-v_{d 0} / s\right\}=\left\{r_{a}+s L_{d 0}(s)\right\}\left\{I_{d}(s)-i_{d 0} / s\right\} \\
\left\{V_{f}(s)-v_{f 0} / s\right\}=s G_{f}{ }^{\prime \prime}(s)\left\{I_{d}(s)-i_{d 0} / s\right\} \\
L_{d 0}(s)=l_{a}+L_{m d} D_{d} /\left(s L_{m d} C_{d}+D_{d}\right) \\
s G_{f}{ }^{\prime \prime}(s)=s L_{m d} /\left(s L_{m d} C_{d}+D_{d}\right)
\end{array}\right\}
$$

これより，(23)，(25)式に基づいて $L_{d}(s) ， L_{d 0}(s)$, $G_{f}(s), G_{f}^{\prime \prime}(s)$ の 4 個の伝達関数の特性を測定すれば
先の二端子対回路の四端子定数を独立に決定てきるこ とがわかる。

このように，周波数応答試験法は各伝達関数の特性 を周波数領域で算定し，それを基に等価回路を構成す る手法であり，広い範囲にわたる伝達関数の特性が得 られ，それを基にかなり精確な回路構成を行うこと ができる。ただし，静止周波数㐫答試験には幾つかの 問題点も指摘されており，代表的なものは次の二点て ある。第一に，增分透磁率の問題がある ${ }^{(26)}$ 。前述の ような広い周波数範囲を出力できるような電源の容量 には限界があり，多くの場合に試験時におりる鉄心の 磁束レベルが試験機の通常運転状態における磁束レべ ルに比較してはるかに小さくなり，透磁率の值がかな り異なってくる。例えば，(22)式の第一式の形で $L_{d}$ を求めると, 磁気飽和の影響がないにもかかからず, その值は通常の測定より得られる不飽和值よりも更に 小さな值となることが指摘されている(文献(20) p. 1482，(19)Part-1，p.3-11]。これに対しては， $L_{m d}$ には通常の磁束レベルにおける別の測定より得られる 不飽和值を用い， $L_{m q}$ に対しても $L_{m d}$ と同じ割合で 修正する方法 ${ }^{(20)}$ が提案されている。第二に，静止状 態における試験であるので，運転時における特有の影 響が考慮できないという問題がある。具体的には，夕 一ビン発電機において回転に伴う遠心力によりスロッ トくさびなどにより構成されている制動回路における 接触抵抗値が変化することが指摘されており(文献 (30)p. 85)，特につなぎ目なしのくさびを用いている 場合にこの影響が顕著になると言われている(文献 (19) Part-1，p.7-7J。以上のような問題点を克服す るための方法として, 通常運転状態において微小な正 弦波信号を例えば AVR 信号に重冨してそのときの各 状態量を測定し，等価回路より得られる応答がその測 定値に一致するように回路定数を修正するオンライン 周波数応答試験法 ${ }^{(23)}$, 線路開閉などに伴う過渡時に おりる各状態量の測定値の周波数スペクトラム处理に 上り各伝達関数の特性を求める方法 ${ }^{(24)}$, 任意回転数 時において電機子側一線地絡を生じさせ，そのときの 定常地絡電流の周波数処理により伝達関数の周波数特 性を求める方法(28)(31)(32)などが提案されている。

$\langle 5 \cdot 2\rangle$ 三相突発短絡試験 三相突発短絡試験に 関して，簡単のため電機子過渡現象を無視し，更に電 機子抵抗も無視して検討する。後者の近似は電機子時 定数の算定を除いて通常行われるものであり, 前者の 近似は固定子三相短絡電流中の直流成分扔よび第二調 波分（ $d, q$ 軸電流中の基本周波交流成分）を考慮し ないことを意味する。この場合の関係式注，(13)， 
（15）式に上記の近似を導入し，電機子電圧を 0, 界磁 電圧を一定, 回転子角速度を同期角速度 $\omega$ とし, 更 に発電機運転を基準として電機子電流の符号を逆転 して,

$$
\left.\begin{array}{rl}
-v_{d 0} / s & =-\omega\left\{\Psi_{q}(s)-\psi_{q 0} / s\right\} \\
& =\omega L_{q}(s)\left\{I_{q}(s)-i_{q 0} / s\right\} \\
-v_{q 0} / s & =\omega\left\{\Psi_{d}(s)-\psi_{d 0} / s\right\} \\
& =-\omega L_{d}(s)\left\{I_{d}(s)-i_{d 0} / s\right\}
\end{array}\right\}
$$

となり,これより次式が得られる。

$$
\left.\begin{array}{l}
i_{d}=i_{d 0}+\left(v_{q 0} / \omega\right) \mathcal{L}^{-1}\left[1 / s L_{d}(s)\right] \\
i_{q}=i_{q 0}-\left(v_{d 0} / \omega\right) \mathcal{L}^{-1}\left[1 / s L_{q}(s)\right]
\end{array}\right\}
$$

上式は負荷時三相短絡に対しても適用できる式である が，通常行われる無負荷三相突発短絡試駼に対しては $i_{d 0}, i_{q 0}, v_{d 0}$ を 0 とおき，更に

$$
v_{90}=\sqrt{3} E_{0}
$$

とおけばよい。ただし， $E_{0}$ は短絡前の無負荷誘導起 電力 (相電圧実効值) である。

さて，(27)式のラプラス逆変換部分を(22)式より

$$
\begin{aligned}
\frac{1}{s L_{d}(s)}= & \frac{1}{s L_{d}}+\left(\frac{1}{L_{d}{ }^{1}}-\frac{1}{L_{d}}\right) \frac{T_{d \mathbf{1}}}{1+s T_{d 1}} \\
& +\cdots+\left(\frac{1}{L_{d}{ }^{N}}-\frac{1}{L_{d}{ }^{N-1}}\right) \frac{T_{d N}}{1+s T_{d N}}
\end{aligned}
$$

と部分分数に展開すれば

$$
\begin{aligned}
i_{d}= & \left(v_{q 0} / \omega\right)\left[\frac{1}{L_{d}}+\left(\frac{1}{L_{d}{ }^{1}}-\frac{1}{L_{d}}\right) e^{-t / T_{d 1}}\right. \\
& \left.+\cdots+\left(\frac{1}{L_{d}{ }^{N}}-\frac{1}{L_{d}^{N-1}}\right) e^{-t / T_{d} N}\right]
\end{aligned}
$$

が得られる。ただし，展開定理により，例えば過渡イ ンダクタンス $L_{d}{ }^{1}$ は

$$
\frac{1}{L_{d}{ }^{1}}=\frac{1}{L_{d}}\left[1-\frac{\left(T_{d 1}-T_{d 01}\right) \cdots\left(T_{d 1}-T_{d 0 N}\right)}{T_{d 1}\left(T_{d 1}-T_{d 2}\right) \cdots\left(T_{d 1}-T_{d N}\right)}\right]
$$

となる。従って, 三相固定子基本波短絡電流の振幅包 絡線の測定結果を(30) 式の形で近似するとして各イン ダクタンス, 時定数の值を求め, (31) 式などの関係式 よりほかの時定数 ( $T_{d 01}$ など) の值も求めることによ りオペレーショナルインダクタンスが決定される。ま た, 界磁電流測定結果の同様な処理により, 伝達関数 $G_{r}(s)$ も決定することができる。

以上のことから明らかなように, 三相短絡試験恰各 伝達関数を展開定理に基づき部分分数で表し, 時間領 域て求まる測定結果が対応する指数関数の和で表され ると近似し，同者の整合性を用いて伝達関数式を決定
する方法であるということができる。なお，通常(31) 式の関係式として

$$
L_{d}{ }^{1}=L_{d} T_{d 1} / T_{d 01}
$$

などの簡略化した式が用いられる場合が多いが，この ことによる誤差は場合によって無視しえないことが指 摘されている(25)。

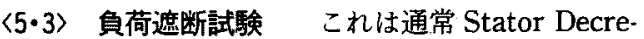
ment Test ${ }^{(14)(15)}$ と呼ばれるものであり，三相短絡試験 とは逆にある負荷のもとで運転している状態で電機子 を開放したときの, 電機子誘起電圧や界磁電流を測定 することにより定数を決定する試験である。前節と全 く同様の仮定に基づいて検討すると，この場合の関係 式住

$$
\left.\begin{array}{l}
\left\{V_{d}(s)-v_{d 0} / s\right\}=\omega L_{q}(s)\left(-i_{q 0} / s\right) \\
\left\{V_{q}(s)-v_{q 0} / s\right\}=-\omega L_{d}(s)\left(-i_{d 0} / s\right)
\end{array}\right\}
$$

となり,これょり次式が得られる。

$$
\left.\begin{array}{l}
v_{d}=v_{d 0}-\left(i_{q 0} \omega\right) \mathcal{L}^{-1}\left[L_{q}(s) / s\right] \\
v_{q}=v_{q 0}+\left(i_{d 0} \omega\right) \mathcal{L}^{-1}\left[L_{d}(s) / s\right]
\end{array}\right\}
$$

例えば，電機子開放前に純誘導負荷に接続されて運転 していたとすると，

$$
v_{d 0} \fallingdotseq i_{40} \fallingdotseq 0
$$

とおくことができ，これより以下のように $L_{d}(s)$ の同 定を行うことができる。つまり，(34)式のラプラス逆 変換部分を(22)式上り

$$
\begin{aligned}
\frac{L_{d}(s)}{s}= & \frac{L_{d}}{s}+\left(L_{d 1}-L_{d}\right) \frac{T_{d 01}}{1+s T_{d 01}} \\
& +\cdots+\left(L_{d}{ }^{N}-L_{d}{ }^{N-1}\right) \frac{T_{d 0 N}}{1+s T_{d 0 N}}
\end{aligned}
$$

と部分分数に展開すれば

$$
\begin{gathered}
v_{q}=v_{q 0}+\left(i_{d 0} \omega\right)\left[L_{d}+\left(L_{d}{ }^{1}-L_{d}\right) e^{-t / T_{d 01}}\right. \\
\left.+\cdots+\left(L_{d}^{N}-L_{d}^{N-1}\right) e^{-t / T_{d 0} N}\right]
\end{gathered}
$$

が得られる。ただし，例えばこの場合の過渡インダク タンス $L_{d}{ }^{1}$ を求めると

$$
\begin{aligned}
L_{d}{ }^{1}= & L_{d} \\
& \times\left[1-\frac{\left(T_{d 01}-T_{d 1}\right) \cdots\left(T_{d 01}-T_{d N}\right)}{T_{d 01}\left(T_{d 01}-T_{d 02}\right) \cdots\left(T_{d 01}-T_{d 0 N}\right)}\right]
\end{aligned}
$$

となる。よって, 電機子誘導電圧の測定結果を(37)式 で近似するとして各インダクタンス, 時定数の值を求 め, (38) 式などの関係式よりほかの時定数 $\left(T_{d 1}\right.$ など) も求めてオペレーショナルインダクタンスが決定され る。また, 界磁電流測定結果の同様な処理により, 
(25) 式の伝達関数 $G_{f}^{\prime \prime}(s)$ を求めることができる。な お，三相突発短絡試験と異なり，本試験においては負 荷と界磁電流の調整により $i_{d 0}=0$ なる状態を比較的 容易に実現できるので, $L_{q}(s)$ の同定も可能であ $ろ^{(15)}$ 。

以上のことから, Decrement 試験は三相突発短絡 試験の場合と同様に各伝達関数を部分分数で表し，時 間領域で求まる測定結果との整合性を用いて伝達関数 式を決定する方法であるということができると同時 に,三相突発短絡試鈳と基本的に双対の関係にあるこ とが容易に理解できる。すなわち, 三相突発短絡試験 は電圧急変に対する応答試験であり, Decrement 試 験は電流急変に対する応答試験であるといえる。な お，(31)式と (38) 式が一致しないことは重要である。 これは，それぞれの試験に対応する過渡インダクタン スなどの意味が異なり，当然その值も互いに異なるこ とを示唆している(29)。

\section{6.あとがき}

本論文では, 同期機の $d, q$ 軸等価回路ならびに電 気的過渡現象解析のための基本式における一般的な性 質に関して検討を行った。従来より種々の形の $d, q$ 軸等洒回路が示されているが，これらの差異は基本的 にその制動回路部分の構成である。そこで，本論文で はまず初めに制動回路, 界磁回路よりなる回転子回路 部分をブラックボックスとして二端子対回路で扱うこ とにより一般的な形で基本式を導出した。次に，この 基本式に現れる 4 個の伝達関数の基本的な性質に関し て検討を加え，境界条件を明確にし，更にその有理関 数表現, 等価回路構成との関係について述べた。最後 に，これら伝達関数の決定にその基整を圆いている代 表的な 3 種の試験法, すなわち周波数応答試験, 三相 突発短絡試験, Decrement 試験を取上げ，その原理 を説明すると共に試験法自体の意味を明確にした。

以上のように，本論文は同期機の基本式の構成から 出発してその定数决定法との関連まで一貫した形でま とめたものであり，同期機の等価回路および基本式に 関する基礎的理論の把握のための資料として有用であ ると考えられる。

最後に, 日ごろより御指導いただく北海道大学工学 部長谷川 淳教授に感謝いたします。

(平成 2 年 7 月 2 日受付)

\section{文献}

(1) C. Concordia: Synchronous Machines. Chap. \& (1951) John Wiley \& Sons
(2) B. Adkins \& R.G. Harley: The General Theory of Alternating Current Machines, Chap. 4 (1975) Chapman and Hall

(3) P. M. Anderson \& A. A. Fouad: Power System Control and Stability, Chap. 4 (1977) The lowa State Univ. Press

（4）猪狩：電気機械理㖮, p. 162 (昭 52) コロナ社

(5) P.K. Kovacs : Transient Phenomena in Electrical Machines, p. 180 (1984) Elsevier

(6) R. H.Park: "Two-Reaction Theory of Synchronous Machines -Generalized Method of Analysis, Part I". Trans. AIEE, p. 716 (1929)

(7) I. M. Canay: "Causes of Discrepancies on Calculation of Rotor Quantities and Exact Equivalent Diagrams of the Synchronous Machines", IEEE Trans. Poxter Apparatus Syst., PAS-88, 1114 (1969)

(8) W. B. Jackson, et al.: "Direct- and Quadrature-Axis Equivalent Circuits for Solid-Rotor Turbine Generators". ibid. PAS-88. 1121 (1969)

(9) I. M. Canay: "Equivalent Circuits of Synchronous Machines for Calculating Quantities of the Rotor during Transient Processes and Asynchronous Starting (Part I . Turbogenerators)", Brow'n Boveri Revieu, 56, 60 (1969)

(10) I. M. Canay: "Equivalent Circuits of Synchronous Machines for Calculating Quantities of the Rotor during Transient Processes and Asynchronous Starting (Part II. Salent-Pole Machines)", ibid., 57, 134 (1970)

(11) R.P. Schulz, et al. : "Dynamic Models of Turbine Generators Derived from Solid Rotor Equivalent Circuit", IEEE Trans. Poucer Apparatus Syst., PAS-92, 926 (1973)

(12) W. Watson, et al. : "Synchronous Machine Operational Impedance from Low Voltage Measurements at the Stator Terminals", ibid., PAS-93, 777 (1974)

(13) Y. Takeda, et al. : "Determination of Synchronous Machine Parameters Allowing for Unequal Mutual Inductances". Proc. Instren Elect. Engrs, 121. 1501 (1974)

(14) G. Schackshaft, et al.: "'Implementation of New Approach to Determination of Synchronous Machine Parameters from Tests", ibid, 124, 1170 (1977)

(15) F.P. de Mello, et al.: "Derivation of Synchronous Machine Parameters from Tests", IEEE Trans. Power Apparatus Syst., PAS-96. 1211 (1977)

(16) I.M. Canay: "Extended Synchronous Machine Model for the Calculation of Transient Processes and Stability", Elec. Machines \& Electromechanics, 1. 137 (1977)

(17) S. D. Umans, et al. : "Modeling of Solid Rotor Turbogenerators-Part I \& Part II". IEEE Trans. Pouer Apparahis Syst., PAS-97, 269 (1978)

(18) IEEE Task Force on Definitions: "Supplementary Definitions \& Associated Test Methods for Obtaining Parameters for Synchronous Machine Stability Study Simulations", ibid., PAS-99, 1625 (1980)

(19) Ontario Hydro: "Determination of Synchronous Machine Stability Study Constants", EPRI Report. EL-1424. Vol. 2 (1980)

(20) M.E. Coultes et al. : "Synchronous Machine Models by Standstill Frequency Response Test". IEEE Trans. Potter Apparaturs Syst., PAS-100, 1480 (1981)

(21) P. L. Dandeno, et al. : "Validation of Turbogenerator Stability Models by Comparison with Power System Tests". ibid. PAS-100, 1637 (1981)

(22) P. L. Dandeno, et al. : "Development of Datailed Turbogenerator Equivalent Circuit from Standstill Frequency Response Measurements", ibid., PAS-100. 1646 (1981)

(23) P. L. Dandeno. et al. : Adaptation and Validation of Turbogenerator Model Parameters through On-Line Fre. quency Response Measurements". ibid., PAS-100. 1656 (1981)

(24) T. Sugiyama, et al.: "Measurements of Synchronous Machine Parameters under Operating Condition". ibid. PAS-101. 895 (1982) 
(25) I. M. Canay : "Determination of Model Parameters of Synchronous Machines", IEE Proc., 130, 86 (1983)

(26) S. H. Minnich, et al. : "Operational Inductances of Turbine Generators by the Finite-Element Method", IEEE Trans. Power Apparatus Syst., PAS-102, 20 (1983)

(27) J. W. Dougherty, et al. : "Operational Inductance of Tur. bine Generators : Test Data versus Finite-Element Calcu. lations", ibid., PAS-102, 3393 (1983)

(28) F.P.de Mello, et al.: "Determination of Synchronous Machine Electrical Characteristics by Test", ibid., PAS102, 3810 (1983)

(29) I. M. Canay : "Identification and Determination of Synchronous Machine Parameters". Brown Boveri Rev., p. 299 (1984)

(30) IEEE Task Force on Definitions : "Current Usage \& Sug. gested Practices in Power System Stability Simulations for Synchronous Machines", IEEE Trans. Energy Conver. sion, EC-1, 77 (1986)

(31) E. Eitelberg, et al.: "Estimating Synchronous Machine Electrical Parameters from Frequency Response Tests". ibid., EC-2, 132 (1987)

(32) J.C.Balda, et al. : "Measurement of Synchronous Machine Parameters by a Modified Frequency Response Method -Part I \& Part II", ibid., EC-2. 646 (1987)

(33) A. Keyhani, et al. : "The Effects of Noise on Frequency Domain Parameter Estimation of Synchronous Machine Models", ibid., EC-4, 300 (1989)

(34) S. E. M. de Oliveira: "Modeling of Synchronous Machines for Dynamic Studies with Different Mutual Couplings between Direct Axis Windings", ibid., EC-4, 591 (1989)

(35) 猪狩：「二軸理論における同期機の界磁側諸茎の変換と単位 法におけるそれらの基沎値」, 電学論 D, 110,32 (平 2-1)

（36）「電力系統の女定化技術」, 電気学会技報（II 部），No. 238, 128 (昭61)

（37）電気学会編：電気工学ハンドブック.p. 916 (昭 63)
(38) IEEE Standard Test Procedures for Obtaining Synchronous Machine Parameters by Standstill Frequency Response Testing, IEEE Std 115A-1987

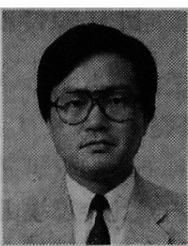

田 村 淳 二(正員)

昭和 32 年 1 月 17 日生。 54 年 3 月室蘭工業大学電気工学科卒業。 59 年 3 月北海道大学大学院工学研究科 博士課程修了。同年 4 月北見工業大 学講師, 61 年 4 月同助教授となり, 現在に至る。工 学博士。主として, 同期機の過渡動特性, 交流励磁形 同期機に関する研究に従事。IEEE 会員。

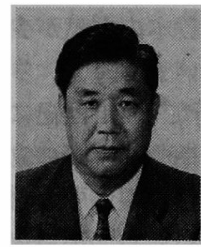

\section{武 田 郁 夫（正員）}

昭和 6 年 8 月 15 日生。 29 年 3 月 北海道大学工学部電気工学科卒業。 同年 4 月北海道炭鉱汽船 (株) 入社。 38 年 4 月北見工業短期大学講師, 43 年北見工業大学助教授, 49 年 10 月同教授となり, 現在に至る。工学博士。主として, 同期機の同期化現 象, 誘導機のベクトル制御に関する研究に従事。 